\title{
Conclusions of the corneal transplant follow up study
}

A Vail, S M Gore, B A Bradley, D L Easty, C A Rogers, W J Armitage, on behalf of collaborating surgeons

University of Leeds Institute of Epidemiology and Health Services Research, Leeds A Vail

MRC Biostatistics Unit, Institute of Public Health, Cambridge S M Gore

University of Bristol Department of Transplantation Sciences, Southmead Health Services, Bristol

B A Bradley

University of Bristol Department of Ophthalmology, Bristol Eye Hospital, Bristol

D L Easty

W J Armitage

United Kingdom Transplant Support Service Authority, Bristol

C A Rogers

Correspondence to: Professor B A Bradley, Department of

Transplantation Sciences, Professorial Unit,

Southmead Health Services, Bristol BS10 5NB.

Accepted for publication 11 March 1997

\begin{abstract}
Aim-On the basis of finalised data from the Corneal Transplant Follow up Study to identify and quantify factors influencing corneal graft outcome in terms of graft survival, rejection, visual acuity, and astigmatism.

Methods-Multifactorial analysis of 2777 grafts registered by the UK Transplant Support Service from July 1987 to June 1991.

Results-Several recipient factors influencing graft survival, rejection, and visual acuity were identified, but no donor factors. Of the operative factors amenable to change, mixed suturing was associated with reduced graft survival, and larger grafts with increased risk of rejection but better visual acuity when surviving. There was increased risk of rejection with poor matching at HLA class I antigens, but mismatched HLA-DR grafts suffered less rejection than those with zero HLA-DR mismatches. Recipient age below 10 years was associated with increased risk of both rejection and graft failure. However, whereas increasing age above 10 years was not associated with differential graft survival, it was significantly associated with decreasing risk of rejection.
\end{abstract}

Conclusions-While confirming possible benefits of HLA-A and B matching, the expense and delay involved in awaiting matched HLA-DR tissue is unlikely to be justified. Other donor factors are unrelated to graft outcome following screening of tissue by eye banks. The highest rates of graft failure and rejection happen in the early postoperative period, and factors influencing visual outcome are also apparent at this stage.

(Br f Ophthalmol 1997;81:631-636)

The Corneal Transplant Follow up Study (CTFS) sought information on grafts performed in the United Kingdom from July 1987 to June $1991 .^{1}$ Detailed analysis of an interim dataset related graft outcome to recipient factors, ${ }^{2}$ donor factors, ${ }^{3}$ including tissue matching, ${ }^{45}$ and operative factors. ${ }^{6}$ Here we present results on the basis of finalised data in order to confirm or refute the findings reported in previous publications.

\section{Methods}

Details of data collection ${ }^{1}$ and analytical method $^{236}$ are given elsewhere. In summary, donor records were made available by the United Kingdom Transplant Support Service Authority (UKTSSA) and Corneal Transplant Service eye banks. Forms concerning recipient medical history, clinical condition, and operative method were sent to surgeons at or around the time of operation. Follow up forms at 3 and 12 months detailed graft status, rejection episodes, and clinical record.

Outcome was assessed in terms of graft survival, time to first occurrence of rejection, and, for functioning grafts, visual acuity and astigmatism. Multifactorial statistical modelling was undertaken to relate each of these outcomes to graft characteristics. Proportional hazards regression was used for assessment of graft survival and time to first rejection. For visual acuity and astigmatism, multiple linear regression was used following logarithmic and square root transformation respectively. Worked examples of use of the coefficients from these models for individual cases are given elsewhere. ${ }^{6}$ From the multitude of potential risk factors, those exercising statistically significant $(p<0.01)$ influence over any of the outcomes were identified by a rational selection procedure. Estimates and 99\% confidence intervals (CI) of the scale of such influence are presented from statistical models incorporating all such factors.

\section{Results}

RESPONSE RATES

Of 4564 grafts recorded by UKTSSA while CTFS was ongoing, $3433(75 \%)$ were registered with CTFS by 381 surgeons returning transplant record forms. Follow up information was not anticipated for 132 grafts, and was provided for 2785 recipients $(84 \%$ of those anticipated), including 2777 (84\%) with sufficient information to be included in analyses of graft survival. Three month forms were returned for $2633(80 \%)$ registered grafts (including 171 recipients reported to have died or been lost to follow up), and 1645 twelve month forms were received $(55 \%$ of those not known to have failed or be otherwise unavailable).

\section{RECIPIENT FACTORS}

Factors exercising significant influence over at least one of the outcome measures were: surgeon experience; recipient age; number of previous grafts; reasons for grafting; diseases in the operated eye; preoperative visual acuity; diagnosis; stromal oedema; active inflammation; deep vascularisation; graft size; suture method; and vitreous surgery (Table 1). 
Table 1 Distribution of characteristics in 2777 grafts included in analyses of graft survival

\begin{tabular}{|c|c|c|c|c|c|}
\hline Factor & Level & Cases (\%) & Factor & Level & Cases (\%) \\
\hline Surgeon & $\begin{array}{l}<50 \text { reports } \\
>50 \text { reports }\end{array}$ & $\begin{array}{r}1934(70) \\
843(30)\end{array}$ & Reasons for graft & $\begin{array}{l}\text { Visual only } \\
\text { Visual and other } \\
\text { Non-visual }\end{array}$ & $\begin{array}{r}2136(77) \\
455(16) \\
186(7)\end{array}$ \\
\hline Recipient age (years) & $\begin{array}{l}0-9 \\
10-19 \\
20-29 \\
30-39 \\
40-49 \\
50-59 \\
60-69 \\
70-79 \\
80+\end{array}$ & $\begin{array}{c}38(1) \\
95(3) \\
328(12) \\
268(10) \\
248(9) \\
280(10) \\
470(17) \\
664(24) \\
386(14)\end{array}$ & Diseases & $\begin{array}{l}\text { Glaucoma } \\
\text { Cataract } \\
\text { Others (excludes uveitis) } \\
\text { (54 posterior chamber) } \\
\text { ( } 30 \text { anterior chamber) } \\
\text { (55 external) } \\
\text { (56 miscellaneous) }\end{array}$ & $\begin{array}{l}368(13) \\
670(24) \\
195(7)\end{array}$ \\
\hline Previous grafts in operated eye & $\begin{array}{l}\text { None } \\
\text { One } \\
\text { Two } \\
\text { More }\end{array}$ & $\begin{array}{c}2294(83) \\
325(12) \\
97(3) \\
61(2)\end{array}$ & Diagnosis & $\begin{array}{l}\text { Keratoconus } \\
\text { Primary endothelial failure } \\
\text { Secondary endothelial failure } \\
\text { Herpes simplex keratitis } \\
\text { Other inflammation } \\
\text { Stromal dystrophy }\end{array}$ & $\begin{array}{l}551(20) \\
361(13) \\
709(26) \\
297(11) \\
417(15) \\
123(4)\end{array}$ \\
\hline Preoperative visual acuity & $\begin{array}{l}<6 / 60 \\
<6 / 24 \\
\geqslant 6 / 24\end{array}$ & $\begin{array}{r}1718(62) \\
603(22) \\
398(14)\end{array}$ & & $\begin{array}{l}\text { Trauma } \\
\text { Others }\end{array}$ & $\begin{array}{l}123(4) \\
196(7)\end{array}$ \\
\hline & Unrecorded & $58(2)$ & Stromal oedema & $\begin{array}{l}\text { Absent } \\
\text { Central }\end{array}$ & $\begin{array}{r}1149(41) \\
411(15)\end{array}$ \\
\hline Active inflammation & $\begin{array}{l}\text { Uveal } \\
\text { Corneal }\end{array}$ & $\begin{array}{l}156(6) \\
288(10)\end{array}$ & & $\begin{array}{l}\text { Diffuse/uniform } \\
\text { Other }\end{array}$ & $\begin{array}{c}1130(41) \\
87(3)\end{array}$ \\
\hline Vascularised & Deep vessels & $660(24)$ & Graft size & $\begin{aligned} \text { Donor + recipient } & \leqslant 14.5 \mathrm{~mm} \\
& \leqslant 15.5 \mathrm{~mm} \\
& >15.5 \mathrm{~mm}\end{aligned}$ & $\begin{array}{r}1034(37) \\
977(35) \\
756(27)\end{array}$ \\
\hline Suture method & $\begin{array}{l}\text { Interrupted } \\
\text { Continuous } \\
\text { Mixed }\end{array}$ & $\begin{array}{r}1210(44) \\
1129(41) \\
438(16)\end{array}$ & & $\begin{aligned} \text { Donor }- \text { Recipient } & =0 \mathrm{~mm} \\
& \leqslant 0.25 \mathrm{~mm} \\
& >0.25 \mathrm{~mm}\end{aligned}$ & $\begin{array}{r}1017(37) \\
658(24) \\
1102(40)\end{array}$ \\
\hline Vitreous & Surgery & 389 (14) & & & \\
\hline
\end{tabular}

Table 2 Factors influencing graft failure

\begin{tabular}{|c|c|}
\hline Factor & $R R(99 \% C I)$ \\
\hline \multicolumn{2}{|l|}{ Surgeon experience } \\
\hline$<50$ reports & 1.00 \\
\hline$>50$ reports & $0.61(0.41,0.91)$ \\
\hline \multicolumn{2}{|l|}{ Recipient age (years) } \\
\hline $0-9$ & $4.58(1.76,11.92)$ \\
\hline $10-19$ & $1.85(0.62,5.55)$ \\
\hline $20-29$ & $1.50(0.66,3.40)$ \\
\hline $30-39$ & $0.86(0.37,2.01)$ \\
\hline $40-49$ & $1.13(0.54,2.35)$ \\
\hline $50-59$ & $1.00(0.51,1.94)$ \\
\hline $60-69$ & $1.19(0.68,2.11)$ \\
\hline $70-79$ & $1.20(0.71,2.03)$ \\
\hline $80+$ & 1.00 \\
\hline \multicolumn{2}{|l|}{ Previous grafts } \\
\hline None & 1.00 \\
\hline One & $1.16(0.73,1.82)$ \\
\hline Two & $2.59(1.41,4.74)$ \\
\hline More & $2.96(1.40,6.22)$ \\
\hline \multicolumn{2}{|l|}{ Reasons for graft } \\
\hline Visual only & 1.00 \\
\hline Visual and other & $1.16(0.76,1.76)$ \\
\hline Non-visual & $1.88(1.10,3.20)$ \\
\hline \multicolumn{2}{|l|}{ Deep vascularisation } \\
\hline No & 1.00 \\
\hline Yes & $1.53(1.07,2.20)$ \\
\hline \multicolumn{2}{|l|}{ Stromal oedema } \\
\hline Absent & 1.00 \\
\hline Central & $1.39(0.79,2.46)$ \\
\hline Diffuse/uniform & $1.86(1.15,3.03)$ \\
\hline Other & $2.85(1.34,6.05)$ \\
\hline \multicolumn{2}{|l|}{ Uveal inflammation } \\
\hline No & 1.00 \\
\hline Yes & $1.78(1.01,3.15)$ \\
\hline \multicolumn{2}{|l|}{ Suture method } \\
\hline Continuous & 1.00 \\
\hline Interrupted & $1.03(0.72,1.47)$ \\
\hline Mixed & $1.57(1.01,2.47)$ \\
\hline
\end{tabular}

GRAFT SURVIVAL

Overall graft survival was $88 \%$ at 12 months (Fig 1). Hazard of graft failure (the risk of a graft failing during a period given that it survived to the start of the period) was highest in the initial 75 day postoperative period, and decreased thereafter to between $1 \%$ and $2 \%$ per 75 day period.
Patients of consultants who reported in excess of 50 grafts during the course of the study had reduced risk of graft failure (Table 2). Grafts in recipients under 10 years of age, those for purely cosmetic and/or therapeutic reasons, and those using a mixture of continuous and interrupted sutures performed less well. Prognosis was worse for regrafts, and where there was deep vascularisation, active uveal inflammation, or stromal oedema. After allowance for these factors, the effect of diagnosis was not statistically significant.

\section{TIME TO FIRST REJECTION}

Rejection free survival was $86 \%$ at 12 months (Fig 2). Hazard of first rejection followed a similar pattern to that of graft failure, but remained high for 150 days before decreasing.

Risk of rejection reduced with increasing recipient age, but was increased for those with glaucoma or with diagnoses of secondary endothelial failure, inflammation, and other less common diagnoses (Table 3). Risk of rejection was increased for regrafts, particularly when two or more grafts had previously failed. Large grafts were also at increased risk of rejection.

For this outcome immunological factors were also considered. We found an adverse effect of matching at class II (HLA-DR) antigens (Fig 3). At each level of class I (HLA-A + HLA-B) mismatch, the class II mismatched group was less likely to reject: relative risk (RR) $(99 \% \quad \mathrm{CI})=0.59$ $(0.35,1.00)$. We had little statistical power to detect an effect of matching at HLA class I antigens owing to the preference given in the tissue allocation scheme to minimising class II mismatches. The estimated detriment of class I mismatching versus no mismatch was of 


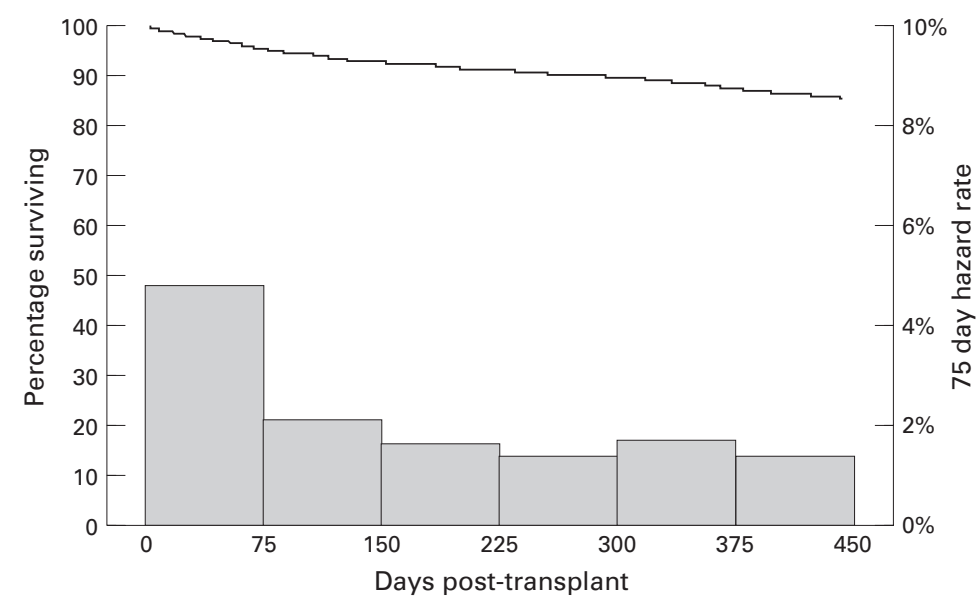

Figure 1 Graft survival and 75 day hazard rates.

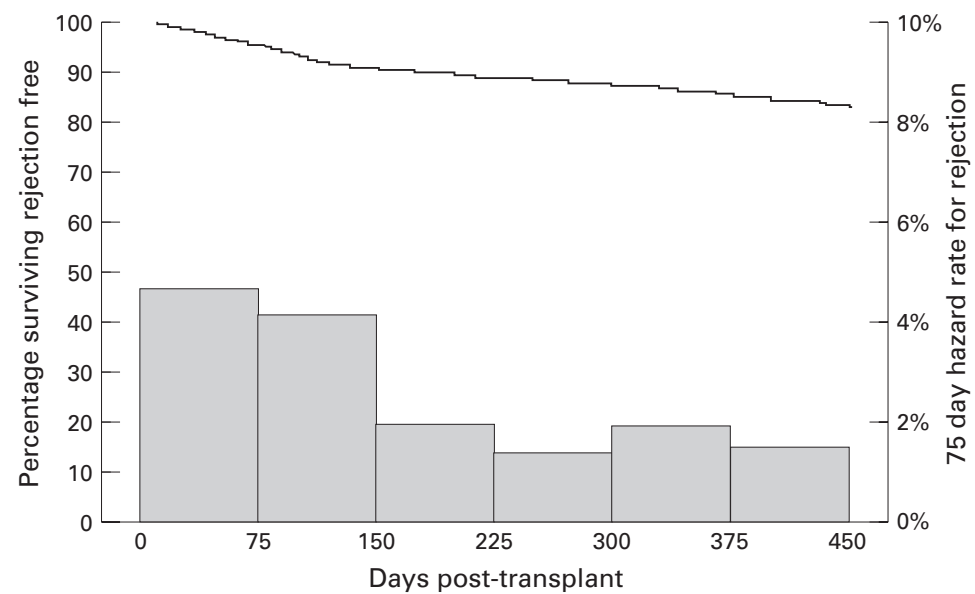

Figure 2 Rejection free graft survival and 75 day hazard rates.

similar scale to the benefit of class II mismatching, but with wider confidence limits: relative risk $(99 \% \mathrm{CI})=1.50(0.51,4.46)$.

VISUAL ACUITY

Distributions of preoperative, 3 month, and 12 month visual acuity in functioning grafts performed for visual reasons (that is, excluding those for purely cosmetic or therapeutic reasons) showed improvement at each stage (Fig 4). Whereas 15\% of grafts performed for visual reasons had preoperative corrected visual acuity of $6 / 24$ or better, $58 \%$ of grafts functioning at 3 months and $70 \%$ of those surviving at 1 year reached this mark.

Only $28 \%$ of the variability at each follow up could be explained by statistical models incorporating all of the factors under consideration. Visual acuity was best for young adults, and poor following regrafts (Table 4). Not surprisingly those with better preoperative visual acuity fared better, whereas those with glaucoma and other diseases fared less well. Diagnoses of keratoconus, stromal dystrophy, and primary endothelial failure carried the best prognosis. Larger grafts performed well, but combined vitreous surgery reduced acuity, particularly in the short term.
ASTIGMATISM

Distributions of preoperative, 3 month, and 12 month dioptres cylinder (DC) in functioning grafts, excluding those performed for purely cosmetic or therapeutic reasons, showed little pattern (Fig 5). Few eyes were refracted preoperatively, but of those that were $77 \%$ had less than 4 DC of astigmatism; $51 \%$ of eyes refracted at 3 months, and $57 \%$ of those refracted at 1 year reached this mark.

Only $5 \%$ of the variability in readings at each follow up could be explained by statistical models incorporating all of the factors under consideration. No factor appeared to be prognostic for 3 month astigmatism. At 12 months, only the 11 recipients aged under 10 years appeared to have significantly reduced astigmatism. For example, where an 80-yearold recipient may have expected $6 \mathrm{DC}$, a young child with similar graft characteristics would have expected 2.5 DC, with $99 \%$ CI from 1.1 DC to 4.5 DC.

\section{Discussion}

The Corneal Transplant Follow up Study constituted one of the largest studies of corneal graft outcome undertaken, involving nearly 400 surgeons on a national basis. Prognosis for graft outcome is by nature multifactorial, and the size of this study allowed detailed statistical modelling of multiple factors. All statistical models make assumptions concerning the data, and those presented here have been validated by methods discussed previously. ${ }^{236}$

Graft survival was $88 \%$ at 1 year, which is comparable with the $91 \%$ reported by the Australian Corneal Graft Registry. ${ }^{7}$ The hazard rate after 6 months for both graft failure and

Table 3 Factors influencing time to first rejection occurrence

\begin{tabular}{|c|c|}
\hline Factor & $R R(95 \% C I)$ \\
\hline \multicolumn{2}{|l|}{ Recipient age (years) } \\
\hline $0-9$ & $4.32(1.43,13.01)$ \\
\hline $10-19$ & $2.60(0.99,6.85)$ \\
\hline $20-29$ & $2.40(1.16,5.00)$ \\
\hline $30-39$ & $1.93(0.97,3.87)$ \\
\hline $40-49$ & $1.55(0.78,3.08)$ \\
\hline $50-59$ & $1.43(0.76,2.71)$ \\
\hline $60-69$ & $1.32(0.75,2.34)$ \\
\hline $70-79$ & $1.19(0.70,2.04)$ \\
\hline $80+$ & 1.00 \\
\hline \multicolumn{2}{|l|}{ Previous grafts in operated eye } \\
\hline None & 1.00 \\
\hline One & $1.39(0.92,2.11)$ \\
\hline Two & $2.66(1.56,4.54)$ \\
\hline More & $2.75(1.34,5.65)$ \\
\hline \multicolumn{2}{|l|}{ Diagnosis of original disease } \\
\hline Keratoconus & 1.00 \\
\hline Primary endothelial failure & $1.48(0.68,3.24)$ \\
\hline Secondary endothelial failure & $2.35(1.17,4.69)$ \\
\hline Herpes simplex keratitis & $1.99(0.99,3.98)$ \\
\hline Other inflammation & $2.43(1.21,4.86)$ \\
\hline Stromal dystrophy & $0.98(0.30,3.20)$ \\
\hline Trauma & $1.94(0.88,4.30)$ \\
\hline Others & $2.28(1.09,4.76)$ \\
\hline \multicolumn{2}{|l|}{ Glaucoma } \\
\hline No & 1.00 \\
\hline Yes & $1.52(1.05,2.21)$ \\
\hline \multicolumn{2}{|l|}{ Graft size } \\
\hline \multicolumn{2}{|l|}{ Donor + recipient } \\
\hline$\leqslant 14.5 \mathrm{~mm}$ & 1.00 \\
\hline$\leqslant 15.5 \mathrm{~mm}$ & $1.43(0.99,2.06)$ \\
\hline$>15.5 \mathrm{~mm}$ & $1.58(1.08,2.31)$ \\
\hline \multicolumn{2}{|l|}{ Donor - recipient } \\
\hline$=0 \mathrm{~mm}$ & 1.00 \\
\hline$\leqslant 0.25 \mathrm{~mm}$ & $0.90(0.59,1.37)$ \\
\hline$>0.25 \mathrm{~mm}$ & $1.19(0.86,1.66)$ \\
\hline
\end{tabular}




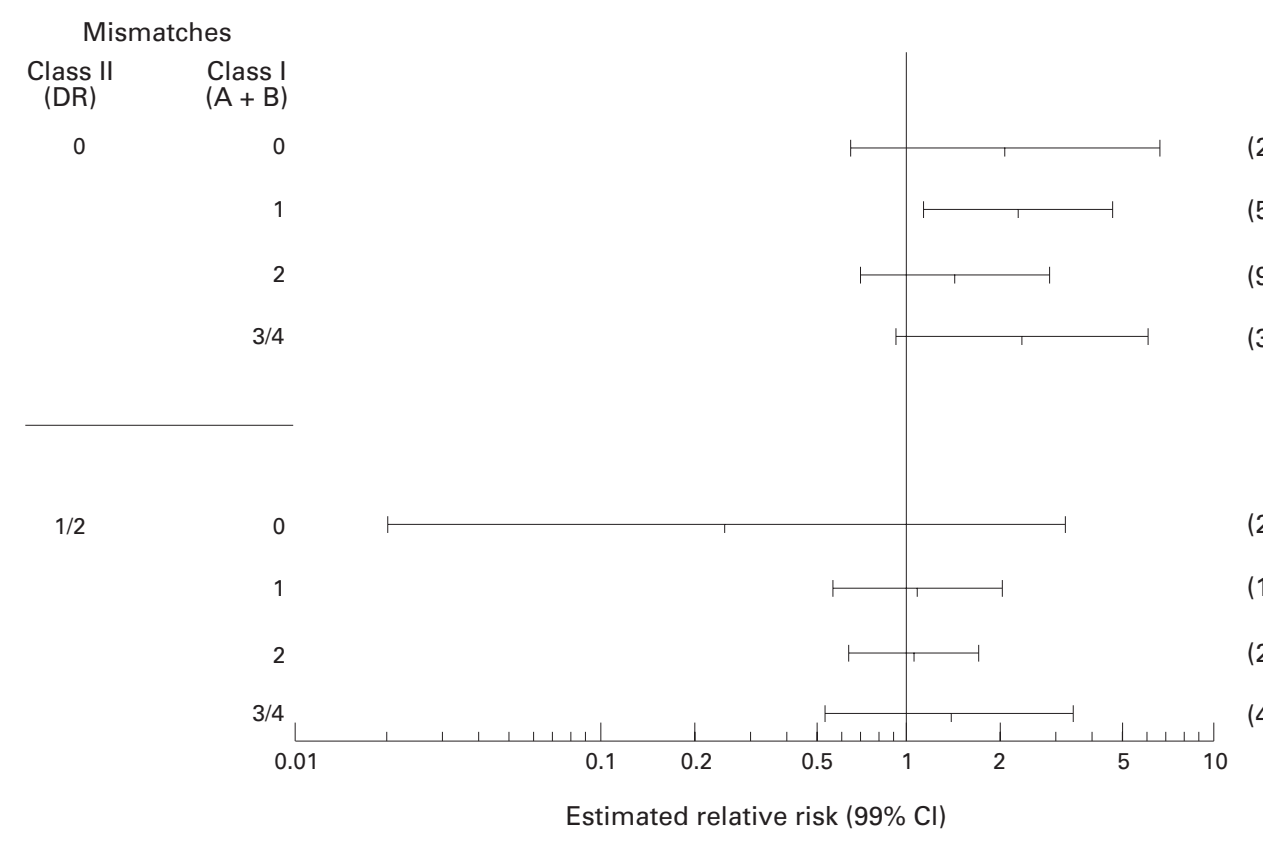

Figure 3 Influence of HLA mismatching on rejection free graft survival, adjusted for other factors.

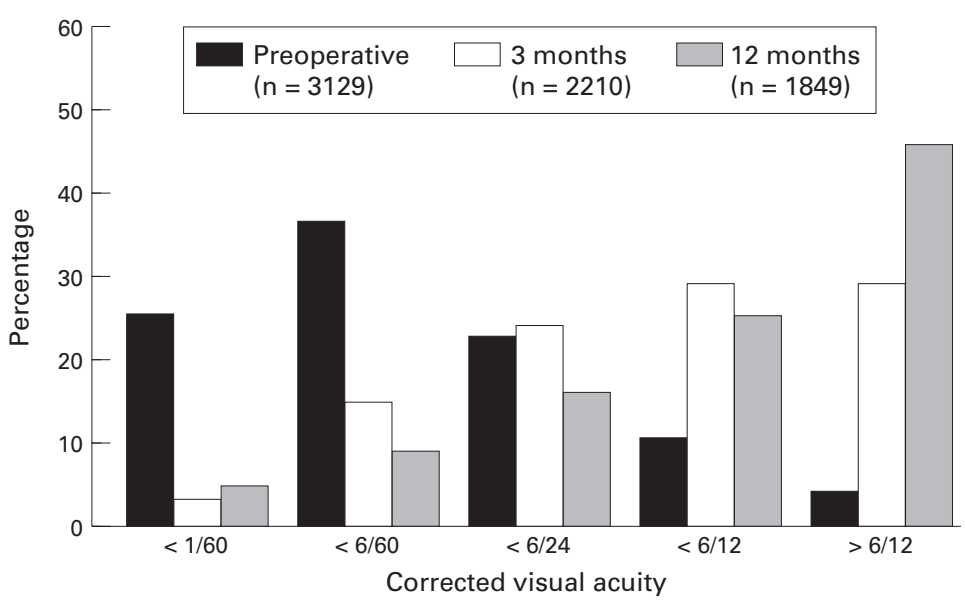

Figure 4 Distributions of corrected visual acuity.

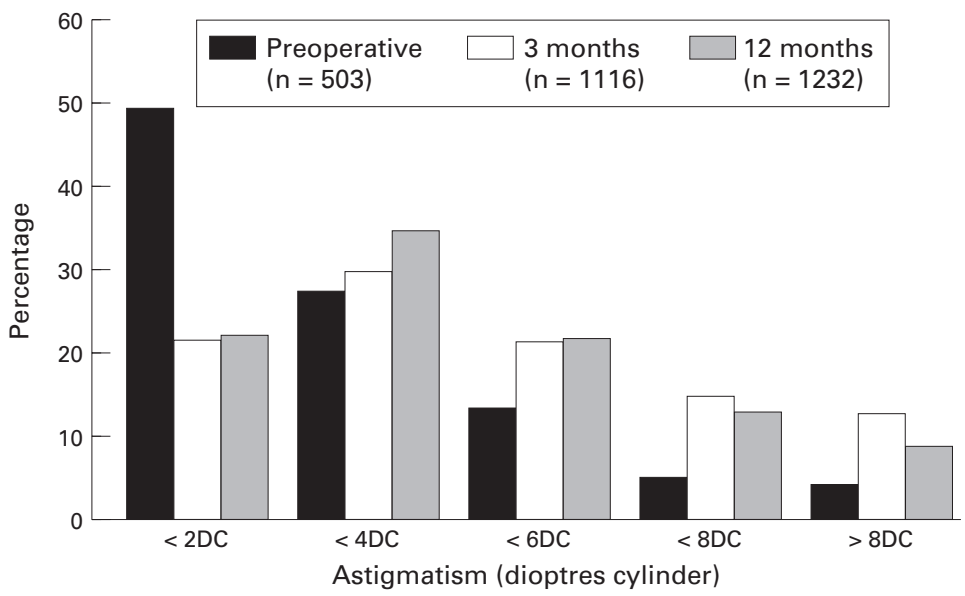

Figure 5 Distributions of astigmatism.

first rejection experience, which may ultimately lead to graft failure, was low. This has important implications for future research. Although different risk factors may come into play over longer term follow up, most 'events' will occur early in the postoperative period, reducing the need for costly long term follow up. However, there is the possibility of a slight increase in both hazard rates at around the 1 year mark. This may represent increased hazard at the time of suture removal.

Our most controversial finding was that grafts mismatched for HLA-DR were less likely to suffer rejection than those with no HLA-DR mismatch. This may be explained theoretically by the 'docking hypothesis'. ${ }^{5}$ The largest clinical study of class II matching, the Antigen Matching Study ${ }^{8}$ of the Collaborative Corneal Transplantation Studies Research Group, found little effect. They reported a relative risk ( $95 \% \mathrm{CI})$ for graft reaction of 1.10 $(0.82,1.48)$, and suggested that the lack of effect may be due to aggressive immunosuppression. Following the report of our interim findings, we conducted a structured overview of published reports. ${ }^{4}$ This concluded that even in high risk cases HLA-DR mismatching is at worst associated with minimal harm (upper 95\% confidence limit 1.25). We recommend that corneal tissue allocation procedures not be based on knowledge of HLA-DR.

We previously reported ${ }^{2}$ a relative risk (95\% CI) of graft failure of $2.36(1.21,4.59)$ for 298 cases with primary endothelial failure versus 457 cases with keratoconus. This result was not apparent in the finalised data with more cases and further adjustment for clinical factors: relative risk ( $95 \%$ CI $)$ was 1.34 $(0.69,2.62)$.

Risk of graft rejection reduced with increasing recipient age. The matching process for most corneas in this series involved some age matching of donor to recipient. While it is possible that the age effect is, therefore, due to age associated changes in donor tissue leading to loss of immunogenicity, use of multifactorial methods implicated the recipient cellular 
Table 4 Factors influencing visual acuity

\begin{tabular}{|c|c|c|}
\hline \multirow[b]{2}{*}{ Factor } & \multicolumn{2}{|l|}{ Coefficient $(99 \%$ CI) } \\
\hline & 3 months & 12 months \\
\hline Baseline & $-1.53(6 / 28)$ & $-1.40(6 / 24)$ \\
\hline \multicolumn{3}{|l|}{ Recipient age (years) } \\
\hline $0-9$ & $-0.14(-1.04,0.77)$ & $-0.46(-1.50,0.58)$ \\
\hline $10-19$ & $0.43(0.03,0.84)$ & $0.48(0.05,0.93)$ \\
\hline $20-29$ & $0.44(0.14,0.74)$ & $0.32(-0.02,0.66)$ \\
\hline $30-39$ & $0.41(0.13,0.70)$ & $0.43(0.11,0.76)$ \\
\hline $40-49$ & $0.27(-0.01,0.55)$ & $0.38(0.06,0.70)$ \\
\hline $50-59$ & $0.28(0.02,0.54)$ & $0.37(0.07,0.67)$ \\
\hline $60-69$ & $0.09(-0.13,0.70)$ & $0.28(0.03,0.52)$ \\
\hline $70-79$ & $0.08(-0.12,0.28)$ & $0.20(-0.02,0.43)$ \\
\hline $80+$ & 0.00 & 0.00 \\
\hline \multicolumn{3}{|l|}{ Previous grafts } \\
\hline None & 0.00 & 0.00 \\
\hline One & $-0.12(-0.31,0.08)$ & $-0.21(-0.43,0.01)$ \\
\hline Two & $-0.61(-0.96,-0.27)$ & $-0.50(-0.93,-0.07)$ \\
\hline More & $-0.69(-1.16,-0.21)$ & $-0.49(-1.00,0.02)$ \\
\hline \multicolumn{3}{|l|}{ Reasons for graft } \\
\hline \multicolumn{3}{|l|}{ Cosmetic } \\
\hline No & 0.00 & 0.00 \\
\hline Yes & $-0.27(-0.50,-0.04)$ & $-0.13(-0.39,0.12)$ \\
\hline \multicolumn{3}{|l|}{ Diagnosis } \\
\hline Keratoconus & 0.00 & 0.00 \\
\hline Primary EF & $-0.16(-0.45,0.12)$ & $-0.09(-0.41,0.23)$ \\
\hline Secondary EF & $-0.68(-0.96,-0.40)$ & $-0.63(-0.95,-0.31)$ \\
\hline HSK & $-0.26(-0.53,0.01)$ & $-0.37(-0.68,-0.07)$ \\
\hline Other inflammation & $-0.35(-0.62,-0.08)$ & $-0.43(-0.74,-0.13)$ \\
\hline Stromal dystrophy & $-0.05(-0.38,0.27)$ & $0.03(-0.34,0.41)$ \\
\hline Trauma & $-0.56(-0.91,-0.21)$ & $-0.89(-1.28,-0.50)$ \\
\hline Others & $-0.69(-0.99,-0.38)$ & $-0.92(-1.27,-0.58)$ \\
\hline \multicolumn{3}{|l|}{ Glaucoma } \\
\hline No & 0.00 & 0.00 \\
\hline Yes & $-0.41(-0.60,-0.22)$ & $-0.63(-0.85,-0.41)$ \\
\hline \multicolumn{3}{|l|}{ Other eye diseases } \\
\hline No & 0.00 & 0.00 \\
\hline Yes & $-0.26(-0.51,-0.01)$ & $-0.14(-0.42,0.14)$ \\
\hline \multicolumn{3}{|l|}{ Preoperative VA } \\
\hline$<6 / 60$ & 0.00 & 0.00 \\
\hline$<6 / 24$ & $0.34(0.19,0.49)$ & $0.41(0.24,0.58)$ \\
\hline$\geqslant 6 / 24$ & $0.41(0.22,0.59)$ & $0.47(0.27,0.67)$ \\
\hline Unrecorded & $0.23(-0.29,0.76)$ & $0.08(-0.63,0.79)$ \\
\hline \multicolumn{3}{|l|}{ Graft size } \\
\hline \multicolumn{3}{|l|}{ Sum } \\
\hline$\leqslant 14.5 \mathrm{~mm}$ & 0.00 & 0.00 \\
\hline$\leqslant 15.5 \mathrm{~mm}$ & $0.16(0.02,0.30)$ & $0.08(-0.08,0.24)$ \\
\hline$>15.5 \mathrm{~mm}$ & $0.14(-0.02,0.30)$ & $0.19(0.01,0.37)$ \\
\hline \multicolumn{3}{|l|}{ Difference } \\
\hline$=0 \mathrm{~mm}$ & 0.00 & 0.00 \\
\hline$\leqslant 0.25 \mathrm{~mm}$ & $0.07(-0.10,0.23)$ & $0.16(-0.03,0.34)$ \\
\hline$>0.25 \mathrm{~mm}$ & $0.02(-0.12,0.16)$ & $0.11(-0.05,0.27)$ \\
\hline \multicolumn{3}{|l|}{ Vitreous surgery } \\
\hline No & 0.00 & 0.00 \\
\hline Yes & $-0.28(-0.47,-0.09)$ & $-0.07(-0.30,0.15)$ \\
\hline
\end{tabular}

$\mathrm{EF}=$ endothelial failure; HSK $=$ herpes simplex keratitis.

immunity. We have been unable to identify previous reports of such an effect, although this may be due to others' use of inappropriate statistical methods. Age is associated with factors such as diagnosis, previous graft history, and glaucoma so that effects may be missed by unifactorial analyses. Indeed, reanalysis of our data in isolation from other factors (results not given) misses the recipient age effect.

We speculatively propose the following mechanism for biological plausibility. In normal individuals aging is associated with alteration of $\mathrm{T}$ cell subtypes and changing responsiveness to cytokines accompanied by thymic involution. The bulk of the thymic tissue begins to decline at birth and continues at 3\% per annum until middle age when it decelerates to $1 \%$ per annum. ${ }^{9}{ }^{10}$ Unlike $\mathrm{B}$ cell immunity, $\mathrm{T}$ cell immunity relies increasingly on clones of committed memory $\mathrm{T}$ lymphocytes that may react to immunogenic epitopes with little or no cross reactivity with histocompatibility alloantigens. ${ }^{11-14}$ The lack of capacity to expand truly novel clones may thus lead to a reduced potential to reject.

Factors influencing visual acuity at 12 months were already apparent in the analysis of short term visual acuity. This was true despite the continuing improvement generally in visual acuity over the intervening period. This suggests that short term follow up may be adequate for research purposes. However, at neither time point was more than $30 \%$ of the variability in visual acuity explained. In the case of astigmatism, even less of the variability was explained, despite collecting detailed information on operative methods in addition to preoperative clinical condition.

Only one factor under the control of surgeons was beneficial for one outcome measure but detrimental for another. Large grafts were at increased risk of rejection, but those which survived achieved better visual acuity at both 3 and 12 months. In common with others using multifactorial analyses ${ }^{15}$ but not those analysing graft size in isolation, ${ }^{76}$ we previously reported reduced risk of graft failure for larger grafts. This effect was not statistically significant in the finalised data.

Far more is now known concerning corneal transplantation in the United Kingdom than was known at the outset of CTFS. Corneal Transplant Service eye banks store donor tissue in organ culture, allowing time for screening which negates the effect of donor factors on graft outcome. ${ }^{17}$ This has led to a dramatic increase in the number of registered grafts. However, the size of the donor pool remains static, suggesting that the corneal transplantation community can ill afford to be complacent. ${ }^{18}$

Further studies should seek to identify reasons for the higher graft survival rates reported by the most experienced surgeons. Differences may in part be due to experience in postoperative care, particularly in the identification and management of astigmatism and other complications.

A list of collaborating surgeons is given in the appendix of reference 1 .

1 Vail A, Gore SM, Bradley BA, Easty DL, Rogers CA. Corneal transplantation in the United Kingdom and Republic of Ireland. Br f Ophthalmol 1993;77:650-6.

2 Vail A, Gore SM, Bradley BA, Easty DL, Rogers CA. Corneal graft survival and visual outcome: a multi-center study. Ophthalmology 1994;101:120-7.

3 Vail A, Gore SM, Bradley BA, Easty DL, Rogers CA, Armitage WJ. Influence of donor, storage and histocompatibility factors on corneal graft outcome. Transplantation 1994;58:1210-6.

4 Gore SM, Vail A, Bradley BA, Easty DL, Rogers CA, Armitage WJ. HLA-DR matching in corneal transplantation: systematic review of published evidence. Transplantation 1995;60:1033-9.

5 Bradley BA, Vail A, Gore SM, Rogers CA, Armitage WJ, Nicholls S, et al. Negative effect of HLA-DR matching on corneal transplant rejection. Transpl Proc 1995;27:1392-4.

6 Vail A, Gore SM, Bradley BA, Easty DL, Rogers CA, Armitage WJ. Clinical and operative factors influencing corneal graft survival, visual acuity and astigmatism. Ophthalmology 1996;103:41-9.

7 Williams KA, Roder D, Esterman A, Muehlberg SM, Coster DJ. Factors predictive of corneal graft survival: report from the Australian Corneal Graft Registry. Ophthalmology 1992;99:403-14.

8 Collaborative Corneal Transplantation Studies Research Group. The Collaborative Corneal Transplantation Stud- 
ies (CCTS): effectiveness of histocompatibility matching in high-risk corneal transplantation. Arch Ophthalmol 1992 110:1392-403.

9 George AJT, Ritter MA. Thymic involution with ageing: obsolescence or good housekeeping? Immunol Today 1996 17:267-72.

10 Steinmann GG, Klaus B, Muller-Hermelink HK. The involution of the ageing human thymic epithelium is independA morphometric study. Scand f Immunol 1985;22:563-75.

11 Sansoni P, Cossarizza A, Brianti V, Fagnoni FF, Snelli G, Monti D, et al. Lymphocyte subsets and natural killer cell activity in healthy old people and centenarians. Blood 1993; 82:2767-73.

12 Franceschi C, Monti D, Sansoni P, Cossarizza A. The immunology of exceptional individuals: the lesson of centenarians. Immunol Today 1995;16:12-6.

13 Fagnoni FF, Vescovini R, Mazzola M, Bologna G, Nigro E Lavagetto G, et al. Expansion of cytotoxic CD8+ CD28- T cells in healthy ageing people, including centenarians. Immunology 1996;88:501-7.

14 Pawelec G, Adibzadeh M, Pohla H, Schaudt K. Immunosenescence: ageing of the immune system. Immunol Today 1995;16:420-2.

15 Sanfilippo F, MacQueen JM, Vaughn WK, Foulks GN. Reduced graft rejection with good HLA-A and B matching in high-risk corneal transplantation. $N$ Engl $f \mathrm{Med}$ 1986;315:29-35.

16 Völker-Dieben HJ, D’Amaro J, Kok-Van Alphen CC. Hierarchy of prognostic factors for corneal graft survival. Aust NZ 7 Ophthalmol 1987;15:11-8.

17 Armitage WJ, Easty DL. Factors influencing suitability of organ-cultured corneas for transplantation. Invest Ophthalmol Vis Sci 1997;38:16-24.

18 Tullo AB, Dyer PA. Corneal transplantation (editorial). BMF 1995;310:1374. 